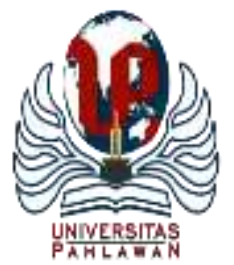

Edukatif : Jurnal Ilmu Pendidikan Volume 3 Nomor 6 Tahun 2021 Halm 3786 - 3793

EDUKATIF: JURNAL ILMU PENDIDIKAN

Research \& Learning in Education

https://edukatif.org/index.php/edukatif/index

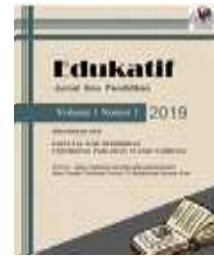

\title{
Development of Assignment-Based Teaching Materials and Local Wisdom for English Learning of Iisbud Sarea Students During the Pandemic
}

\author{
Samsudin $^{1 凶}$, Sukarismanti $^{2}$ \\ Institut Ilmu Sosial dan Ilmu Budaya Samawa Rea, Sumbawa, Indonesia ${ }^{1,2}$ \\ E-mail : syamsamsudin18@ gmail.com ${ }^{1}, \underline{\text { Sukarismanti@gmail.com }}^{2}$
}

\begin{abstract}
Abstrak
Tujuan penelitian ini adalah untuk mengembangkan bahan ajar berbasis tugas dan kearifan lokal untuk pembelajaran bahasa Inggris mahasiswa Iisbud Sarea dimasa pandemi. Kemudian, metode penelitian ini menggunakan model pengembangan ADDIE yaitu analysis, design, development, implementation, and evaluation. Hasil penelitian menunjukkan bahwa hasil uji validasi ahli materi, ahli bahasa dan media terhadap modul yang dikembangkan berada pada kategori "tinggi" dan "sanggat tinggi". Kemudian, hasil uji kepraktisan baik dari segi mahasiswa maupun dosen pengampuh bahwa modul berada pada kategori "praktis" dan "sangat praktis". Sementara uji keefektifan menunjukkan bahwa modul bahasa Inggris berbasis tugas dan kearifan lokal berada pada kategori praktis di mana hasil uji coba pada mahasiswa program studi ilmu hukum adalah 16 orang yang mendapatkan nilai $\geq 70$ atau 76,2\%, sementara hasil uji coba pada mahasiswa program studi sosiologi adalah 15 orang yang mendapatkan nilai $\geq 70$ atau $77 \%$. Jadi, secara keseluruhan modul bahasa Inggris berbasis tugas dan kearifan lokal berada pada kategori efektif dan telah memenuhi standar keefektifan bahan ajar yang telah ditentukan sebelumnya yaitu $75 \%$ mahasiswa mendapatkan nilai $\geq 70$ atau nilai $\mathrm{B}$.
\end{abstract}

Kata Kunci: Bahan Ajar, Kearifan Lokal, Iisbud Sarea, Pandemi

\section{Abstract}

The purpose of this research is to develop assignment-based teaching materials and local wisdom for the English language learning of Iisbud Sarea students during the pandemic. Then, this research method uses the ADDIE namely development, analysis, design, development, implementation, and evaluation. The results showed that the validation test results of material expert, language expert, and media expert against the modules developed were in the "high" and "very high" categories. Then, the results of the practicality test both in terms of students and English lecturer that the module is in the category of "practical" and "very practical". While the effectiveness test showed that the assignment-based English module and local wisdom are in the practical category where the test results in the law study program are 16 people who get a score of $\geq 70$ or $76.2 \%$. While the test results in the sociology study program are 15 people who get a score of $\geq 70$ or 77\%. Thus, overall the assignment-based English language module and local wisdom are in the effective category and have met the standard of the effectiveness of pre-determined teaching materials, namely $75 \%$ of students get a grade of $\geq 70$ or grade $B$.

Keywords: Teaching Material, Local Wisdom, Iisbud, Pandemic

Copyright (c) 2021 Samsudin, Sukarismanti

$\triangle$ Corresponding author:

Email : syamsamsudin18@gmail.com

DOI : https://doi.org/10.31004/edukatif.v3i6.1107

ISSN 2656-8063 (Media Cetak)

ISSN 2656-8071 (Media Online)

Edukatif : Jurnal Ilmu Pendidikan Vol 3 No 6 Tahun 2021 p-ISSN 2656-8063 e-ISSN 2656-8071 
3787 Development of Assignment-Based Teaching Materials and Local Wisdom for English Learning of Iisbud Sarea Students During the Pandemic - Samsudin, Sukarismanti

DOI: https://doi.org/10.31004/edukatif.v3i6.1107

\section{INTRODUCTION}

The emergence of covid-19 which is considered a pandemic in Indonesia has changed the learning and teaching process. From the learning process with a face-to-face system in the classroom to a home learning system or known as an online system (Dian et al.,2020; Alfonsius, 2020). This is based on the electronic letter number 36962/MPK.A/HK/2020 of the ministry of education and culture about the online learning system and working from home to prevent spreading coronavirus and general department of high education number 262/E.E2/KM/2020 about learning during pandemic coronavirus and number 262/E.E2/KM/2020 about the implementation of education program in the pandemic era. The Minister of Education instructed that learning in universities in both red, yellow, and green zones should organize online learning systems to reduce the spread of covid-19. The condition requires lecturers to use technology in interacting with their students. However, online learning has many drawbacks and challenges such as internet connection, facilities, and human resources (Surahman et al.,2020; Kartini et al.,2021; Primasari et al.,2021). Seeing this condition, most Iisbud Sarea lecturers, especially lecturers who teach English used WhatsApp group as an alternative media to teach and share material. The use of WhatsApp group as a medium is also not effective enough and the teaching materials used are quite common and require it to be delivered in a face-to-face system (offline). Therefore, the condition requires lecturers in developing task-based teaching materials and local wisdom and student skills so that they can develop English skills in the pandemic.

Some previous research on learning is based on local wisdom such as research conducted by (Kusuma, 2016; Sarjono, 2017; Wijaya, 2018; Verawati et al.,2019; Oktariani, 2019; Prihartanti, 2020; Listia et al., 2020; Armawan, 2017; Arvianty, 2020; Nasir, 2020; Supriyono \& Nita, 2017; Marhaeni, 2012). Of all the research conducted by the researchers, the average of relevant research focuses on the development of reading teaching materials and Writing based on local wisdom. In this case, no one has developed teaching materials that combine vocabulary, reading skills, and writing skills. In addition, all teaching materials are developed based on local wisdom outside of Sumbawa island and most of the research is used in elementary, junior high, and high school. This means that this research is different from previous researchers both in terms of skills developed, material content, method, and research objects.

Thus, based on the literature review above that this research is focused on the development of taskbased teaching materials and local wisdom. In addition, this study also developed teaching materials that contain reading skills, vocabulary, and writing skills. Therefore, the purpose of this research is to develop assignment-based teaching materials and local wisdom of Sumbawa island for English language learning of Iisbud Sarea students.

\section{METHOD}

This development research model uses the ADDIE development model (Analysis, Design, Development, Implementation, and Evaluation). The analysis is intended to analyze problems faced by both students and faculty. In addition, researchers analyzed learning tools and learning models used during the Pandemic as well as conducted need analysis. Then, Design aims to write blueprint material and the entire contents of the teaching material. The development aims to develop teaching materials based on local wisdom and conduct validation by materials, language, and media experts on the materials that have been developed. Furthermore, in the implementation stage, at this stage researchers conducted trials of teaching materials that have been developed. The trial was conducted by teaching English using a module that has been developed and then providing a final test to find out the ability of students in answering questions after following the learning using task-based teaching materials and local wisdom. And last is evaluation, on this hold researchers analyzed the practicality and effectiveness of task-based teaching materials and local wisdom for English language learning in the pandemic. 
3788 Development of Assignment-Based Teaching Materials and Local Wisdom for English Learning of Iisbud Sarea Students During the Pandemic - Samsudin, Sukarismanti

DOI: https://doi.org/10.31004/edukatif.v3i6.1107

This research was conducted for 7 months starting from January to July 2021 located at the Institute of Social and Cultural Sciences Samawa Rea, especially in English courses programmed by students of semester II namely the law and sociology study program.

This research data was obtained from several respondents, namely lecturers, material experts, linguists, and media experts. While data collection techniques are conducted using interview technique, FGD with English lecturers, validation questionnaires to experts, the provision of practicality test questionnaires to lecturers and students, the provision of final tests to students, and documentation. Expert validation questionnaire scores use a scale of 1-5 where $1=$ is not very good, $2=$ not $\operatorname{good}, 3=\operatorname{good}$ enough, $4=\operatorname{good}$, and $5=$ very good While the practicality test score uses a scale of $1=5$ where $1=$ strongly disagree, $2=$ disagree, 3 = undecided, and $4=$ agree, and $5=$ strongly agree. Then, the expert validation score and the practicality test are analyzed using the index formula;

$$
\text { index } \%=\frac{\text { Score total }}{\mathrm{Y}} \times 100
$$

Then, the value of validity and practicality test obtained is adjusted to the table of criteria of validity and practicality to know the validity and practicality of task-based modules and local wisdom. Here is a table of criteria for validity and practicality:

Table 1

Criteria for Validity and Practicality of Teaching Materials

\begin{tabular}{ccc}
\hline Score & Interval & Criterion \\
\hline 5 & $81-100$ & Very High/Very Practical \\
\hline 4 & $61-80$ & High/Practical \\
\hline 3 & $41-60$ & High Enough/Practical Enough \\
\hline 2 & $21-40$ & Low/Impractical \\
\hline 1 & $0-20$ & Very Low/Very Impractical \\
\hline
\end{tabular}

The validity criteria table is used to determine the validity of the module before using it. If the validity of the module that has been developed is "high" from both material, language, and media experts then it can be used for field trials. While the table of practical criteria is used to know the practicality level of the teaching materials that have been used. The module is said to be practical if the assessment results of lecturers and students are "practical" and it can be an additional reference for lecturers to improve students' English skills.

\section{RESULT AND DISCUSSION}

In general, this research was conducted in 6 stages, namely needs analysis, blueprint design of teaching materials, development of teaching materials, and expert validation, implementation, and evaluation.

\section{Need Analysis}

To obtain the need analysis data, researchers conducted unstructured interviews with lecturers who taught English about inputs, processes, and outputs in the implementation of English lectures both before the pandemic and learning during the covid-19 pandemic.

In terms of input, lecturers who teach English courses have never taught English using teaching materials based on local wisdom on Sumbawa island to be the area where most students of Iisbud Sarea come from. They teach according to their wishes without being based on curriculum and lesson plans.

In addition, the package book used is a book downloaded from the internet. This is because there is no curriculum, lesson plans, and textbooks developed by lecturers. Then in terms of the process, lecturers only teach based on the lecturer's desire about what material to teach and still conventional by following the instructions from the lecturer's handbook. 
3789 Development of Assignment-Based Teaching Materials and Local Wisdom for English Learning of Iisbud Sarea Students During the Pandemic - Samsudin, Sukarismanti

DOI: https://doi.org/10.31004/edukatif.v3i6.1107

The material is not necessarily by the character and ability of students who are not majoring in English. In addition, the technique of lecturers in teaching English during the pandemic is to provide material contained in the package book through WhatsApp group to be studied by students without using materials that are appropriate to the student's abilities. The result is that the output of students after taking English courses does not provide satisfactory results so the average student's score is quite low. This is also evidenced by the student's inability to answer simple English questions.

\section{Blueprint Design of Teaching Material}

Based on the results of the need analysis, researchers note things that are considered important to support the blueprint design of teaching materials in the form of modules. Before designing the module blueprint, researchers conducted FGD with other English lecturers. FGD results show that several points must be considered in developing teaching materials namely teaching materials must be by student abilities, based on student life activities, and can be used offline and online to help students in understanding English materials and can develop their abilities. In addition, the development of assignment-based teaching materials and local wisdom has the support of other English lecturers who teach in other courses.

Based on the points of the FGD results, the researchers made it as an additional reference to design a module blueprint that suits students' abilities and daily lives. To design the module by the ability and daily life of students, researchers conduct the development of teaching materials in the form of assignment-based modules and local wisdom by taking pictures of cultural activities on Sumbawa island and describing the cultural activities in the form of text. From the text, it was then developed into several activities. The blueprint design of this module is as shown in figure 1 and figure 2 below;

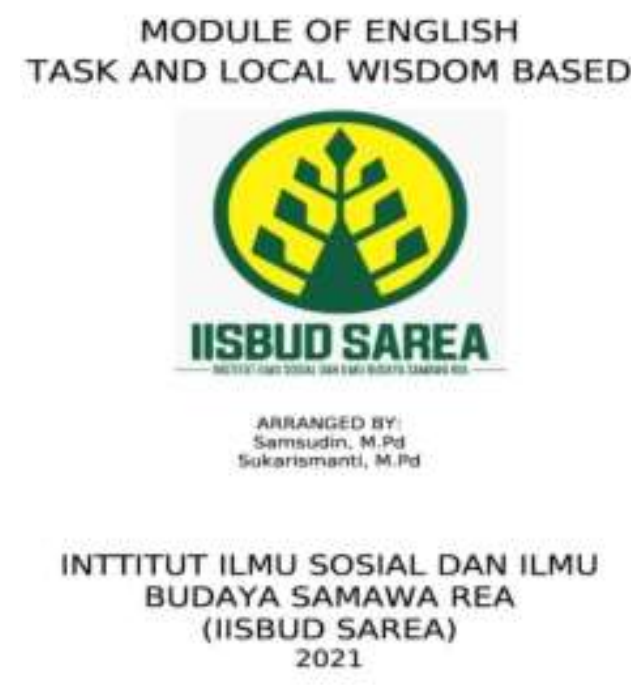

Figure 1. Module Cover of Task and Local Wisdom-Based English 
3790 Development of Assignment-Based Teaching Materials and Local Wisdom for English Learning of Iisbud Sarea Students During the Pandemic - Samsudin, Sukarismanti

DOI: https://doi.org/10.31004/edukatif.v3i6.1107

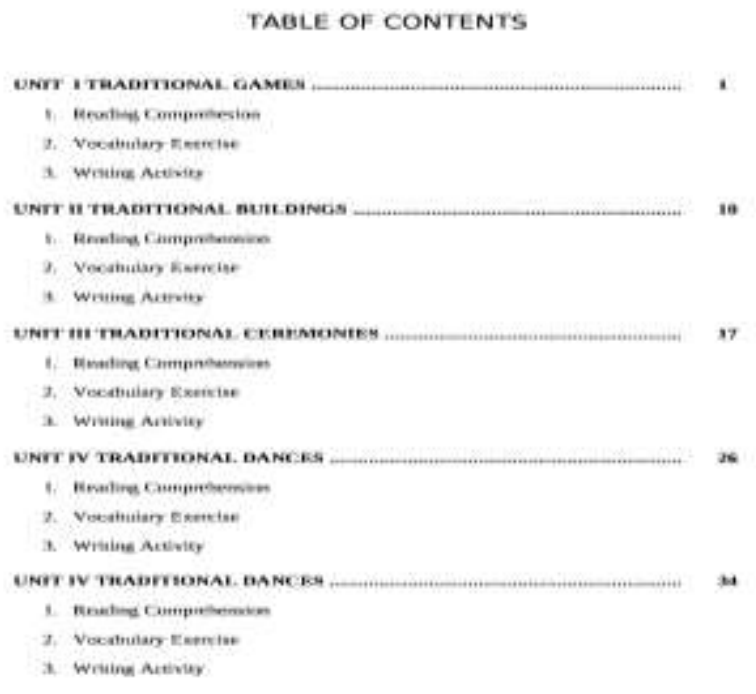

Figure 2. Module Table of Content Design

This teaching material is designed based on the local wisdom of the Sumbawa island for learning English during the pandemic. This teaching material can be used as an additional reference for English lecturers be used during the pandemic, both in online and offline based learning. The material contained in this material is in the form of topics often done by the people on the island of Sumbawa and often witnessed and carried out by students.

The module design consists of 5 units. Each unit consists of 5 different types of reading material, different vocabulary dan writing. The first part is about traditional games which consist of 5 different types of traditional games. The second part is about traditional buildings which consist of 5 types of traditional buildings on the island of Sumbawa. Next about traditional ceremonies, traditional dances, and traditional food. Each topic or teaching material is equipped with pictures that guide students to understand and do the exercises. In addition, each unit ends with exercises that lead students to study independently and includes paragraph writing exercises related to how to make descriptive paragraphs using the clustering technique.

\section{Development}

At this stage, researchers conducted material development based on material classification from module blueprint design to become a module that is ready to be submitted and conducted validation tests by three experts, namely material, language, and media experts. In the module validation test, the researchers provided a validation sheet containing statement points and modules that had been developed for the material experts to fill in. The language validation sheet consists of 7 statement points, while the media validation sheet also consists of 7 statement points that must be assessed by experts.

Validation of materials, languages, and media are each done once because based on the results of expert validation that the module that has been developed are in a high category and very high so there is no need for a second validation test. This is evidenced by the results of the analysis as contained in the table below:

Tabel 2

The Result of Expert Validation on Module

\begin{tabular}{cccc}
\hline Experts & $\sum$ Score & Porcentage $(\boldsymbol{\%})$ & Criterion \\
\hline Materi & 45 & 90 & Very high \\
\hline Bahasa & 32 & 68,5 & High \\
\hline Media & 31 & 88,5 & Very high \\
\hline
\end{tabular}


3791 Development of Assignment-Based Teaching Materials and Local Wisdom for English Learning of Iisbud Sarea Students During the Pandemic - Samsudin, Sukarismanti

DOI: https://doi.org/10.31004/edukatif.v3i6.1107

Based on the validation table above that the module that has been developed has qualified for use in students who are not English majors in which the presentation of material in the module is at $90 \%$ or the category is very high, the presentation of the language is at $91.4 \%$ or the category is very high, and the media is at $88.5 \%$ or in the very high category. This means that the teaching materials that have been developed are feasible to use because they have achieved good instrument standards, including validity [13]. In addition, it can also be used in assignment-based distance learning conditions as well as in face-to-face learning directly in the classroom (offline).

\section{Implementation}

At this stage, researchers implement teaching materials for students of law and sociology studies programs. In addition, researchers conducted tests on the practicality and effectiveness of the modules developed. The results of this test are then used as additional references to enhance the module.

\section{Practicality Test}

In the practicality test, the researcher himself is a lecturer who mastered English courses as well as a user of modules so that the questionnaire sheet is filled based on observations during the implementation of modules in learning. In addition, there is also a practicality test questionnaire for students as the target of the module. Then, the questionnaire was given to students consisting of 46 people. The practicality test questionnaire for lecturers who master the course consists of 7 statement points. While the practicality test questionnaire for students consists of 8 statement points. The results of the module's practicality test are described in the table below:

Table 3

Module Practicality Test Results

\begin{tabular}{cccc}
\hline Experts & $\sum$ Score & Porcentage (\%) & Criterion \\
\hline Lecture & 29 & 83 & Very Praktical \\
\hline Students & 1431 & 78 & Praktical \\
\hline
\end{tabular}

Based on the results of the analysis of the table above that the results of practicality tests by lecturers studying courses are $83 \%$ or the criteria strongly agree to the points of statement that have been given. While the practicality test given to students as the target of this module is $78 \%$ or the category agreed to. Therefore, it can be concluded that this module is very practical to use in students who are not majoring in English both taught online and offline.

\section{Effectiveness Test}

Then test the effectiveness of the module, researchers give the final test to students after using the module for 1 semester. There are two classes of students who are taught using the module, namely 2 ndsemester students of the law study program and students of the sociology study program. Each class consists of 20 sociology students and 26 law students.

Students' final grades after attending lectures. To get the final score, the researchers gave an exam sheet and then analyzed the results to find out the number of students who got a $\geq 70$ or a B. Based on the results of the analysis showed that students of sociology study program that get a score of $\geq 70$ are as much as 15 people or $77 \%$ who get a B. While students of law study program that get a score of $\geq 70$ are as much as 16 people or $76.2 \%$. While the percentage of students who get an average score of $\geq 70$ or B grade from two study programs is $77 \%$. From the results of the analysis and description, it can be said that the task-based English module and local wisdom are in the effective category and have met the standards of the effectiveness of pre-determined teaching materials that $75 \%$ of students get a grade of $\geq 70$ or grade $B$.

\section{Evaluation}

Validation test results from all three material, language, and media experts are in the high category. However, there are additional inputs from validators to improve the content of module materials that have 
3792 Development of Assignment-Based Teaching Materials and Local Wisdom for English Learning of Iisbud Sarea Students During the Pandemic - Samsudin, Sukarismanti

DOI: https://doi.org/10.31004/edukatif.v3i6.1107

been developed such as in terms of language must be refined again so that it corresponds to the level of ability of students. In addition, media experts also recommend adding more than 1 image to each material so that students are familiar with the local wisdom that has been chosen.

Then, during the implementation of assignment-based English learning and local wisdom students are quite enthusiastic and happy to learn English using materials familiar with them. In addition, they also do exercises by the target time given. However, in writing skills, they have not too many vocabularies that they belong to so it affects the development of their writing. In this case, the student only writes one paragraph when asked to describe one of his favorite characters using the clustering technique. However, these conditions are still considered natural because their scientific staleness is different. Therefore, overall both the validation test, module implementation in teaching, practicality test, and effectiveness test run by the target and expectations.

\section{CONCLUSION}

Based on the result and discussion above, this research can be concluded that the teaching materials in the form of assignment-based modules and local wisdom, as well as the results of data analysis and discussion, meet valid categories by both materials, language, and media experts. The results of the analysis showed the module was in the high category and very high. Then on the practicality test, the module shows that it is in the category of very practical in terms of lecturers and the practical category in terms of students. Furthermore, for the effectiveness test, the task-based English module and local wisdom are in the practical category of both the test results in students of the law study program and in students of sociology study program which is $77 \%$. So, overall the modules that have been developed deserve to be used in both online and offline learning.

\section{ACKNOWLEDGEMENT}

This research will not be completed and goes according to plan if there is no support from other parties. Therefore, the researchers thanked the Directorate of Research and Community Service of Higher Education (DRPM Dikti), Kemdikbudristek, and higher education service institutions (Lldikti region VIII Bali-NTB who have provided funding and support so that this study is completed by the target time that has been determined.

\section{REFERENCES}

Alfonsius.(2021). Penyelenggaraan Pembelajaran Perguruan Tinggi Swasta Di Masa Pandemi Covid-19. Journal of Accounting \& Management Innovation. 5(1) 01-10

Armawan I Ketut \& Made Darma Susena Suyasa. (2017). Pengembangan Materi Ajar English for Guiding Berbasis Kearifan Lokal. Seminar Nasional Riset Inovasi. 796-802.

Arvianti Indah \& Ana Wahyuni. (2020). Penerapan Model Pembelajaran Bahasa Inggris Berbasis Kearifan Lokal Sebagai Upaya Konstruktivisme Karakter Anak Bangsa. Proceeding of The URECOL. 90-98.

I. G. N. A. Wijaya Mahardika. (2018). Incorporating Local Culture in English Teaching Material for Undergraduate Students. SHS Web Conf. 42(2). doi: 10.1051/shsconf/20184200080.

I. P. I. Kusuma. (2016). Developing Reading Material for Elementary Students in Tourism Area by Inserting Local Culture. Jeels, 3(1), 109-127. Available:

https://www.google.com/url?sa=t\&rct=j\&q=\&esrc=s\&source=web\&cd=3\&cad=rja\&uact=8\&ved=2ah UKEwiV7tKZ6cfdAhXJtI8KHQ_7BgIQFjACegQIBxAB\&url=http\%3A\%2F\%2Fjurnal.iainkediri.ac.id \%2Findex.php\%2Fjeels\%2Farticle\%2Fview\%2F176\&usg=AOvVaw1GWtVrvZ7ZjA49xlzhd4KT

Kartini Endang, Mimbar Lalu, \& Izrawati. (2021). Tantangan Dalam Pembelajaran Perguruan Tinggi Dan Implementasi Merdeka Belajar Di Masa Pandemi Covid-19. Journal Ilmiah Rinjani (JIR). 9(2), 43-50 
3793 Development of Assignment-Based Teaching Materials and Local Wisdom for English Learning of Iisbud Sarea Students During the Pandemic - Samsudin, Sukarismanti

DOI: https://doi.org/10.31004/edukatif.v3i6.1107

Marhaeni. A.A.I.N. (2012). Language Assessment for Masters' Program of English Language Education. Post Graduate Program, Ganesha University of Bali

Nasir Aco \& Andriani. (2020). Kearifan Lokal dalam Pembelajaran Bahasa Inggris: Sarana Meningkatkan Keterampilan Pelajar Bahasa Inggris Dewasa. Pepatuzdu: Media Pendidikan dan Sosial Kemasyarakatan, 16(2), 133-141. doi: 10.35329/fkip.v16i2.1769

Primasari Ika Firma Ningsih Dian \& Zulela. (2021). Kendala Pembelajaran Jarak Jauh (PJJ) Secara Online Selama Masa Pandemik Covid-19 di Sekolah Dasar. JIKAP PGSD: Jurnal Ilmiah Ilmu Kependidikan. $5(1), 64-73$

Ratu Dian Ayu Uswatun Khasanah, ramudibyanto Hascaryo, \& Widuroyekti Barokah.(2020). Pendidikan Dalam Masa Pandemi Covid-19. jurnal sinestesia. 10(1), 41-48

R. A. Sarjono Owon. (2017). Pengembangan Bahan Ajar Menulis Berbagai Jenis Teks Bertema Kearifan Lokal Sikka Bagi Siswa SMP. JINoP (Jurnal Inov. Pembelajaran), 3(1). 528, 2017, doi: 10.22219/jinop.v3i1.4318.

R. Listia, N. E. Chandra \& E. P. Elyani. (2020). Bahan Ajar Berbasis Kearifan Lokal bagi Guru-Guru MGMP Bahasa Inggris Tingkat SMP Kabupaten Tanah Laut. Bubungan Tinggi J. Pengabdi. Masy., 2(1). doi: 10.20527/btjpm.v2i1.1794.

R. P. J. Oktariyani. (2019). Pengembangan Bahan Ajar Bahasa Inggris Berbasis Local Learning pada Siswa Sekolah Dasar. J. Ilmu Pendidik. STKIP Kusuma Negara. 4(10), 103-115, doi: 10.37640/jip.v11i2.93.

Supriyono Yusup \& Nita Sari Narulita Dewi. (2017). English Language Immersion Berbasis Kearifan Lokal Bagi Siswa Sekolah Dasar. Jurnal Sarwahita. 14(2), 140-144, 2017. doi: 10.21009/sarwahita.142.08.

Surat Edaran Menteri Pendidikan dan Kebudayaan Republik Indonesia Nomor 36962/MPK.A/HK/2020 tentang Pembelajaran secara Daring dan Bekerja dari Rumah dalam Rangka Pencegahan Penyebaran Corona Virus Disease (COVID-19).

Surat Edaran Direktorat Jenderal Pendidikan Tinggi Nomor 262/E.E2/KM/2020 Perihal Pembelajaran Selama Masa Darurat Pandemi COVID- 19.

Surat Edaran Direktorat Jenderal Pendidikan Tinggi Nomor 302/E.E2/KR/2020 Masa Belajar Penyelenggaraan Program Pendidikan.

Surahman Evi, Santaria Rustan, \& Setiawan Edi Indra Setiawan. (2020). Tantangan Pembelajaran Daring Di Indonesia. Kelola: Journal of Islamic Education Management,.5(2), 89 -98

T. A. S. Pipit Prihartanti Suharto. (2020). Analisis Kebutuhan Siswa SD terhadap Bahan Ajar Bahasa Inggris Berbasis Kebudayaan Lokal Sunda. 15(2), 100-109.

Verawati, Mardhatillah, I. Pramuniati, and E. Evianti. (2019). Bahan Ajar Interaktif Berbasis Kearifan Lokal Melalui Pendekatan Saintifik pada Pembelajaran Bahasa Inggris. Genta Mulia. 9(1), 38-53. 